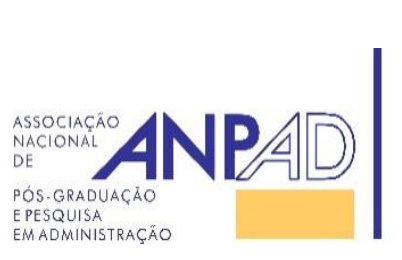
Available online at http://www.anpad.org.br/bar
BAR, Rio de Janeiro, v. 14, n. 1, art. 5, e160097, 2017
http://dx.doi.org/10.1590/1807-7692bar2017160097

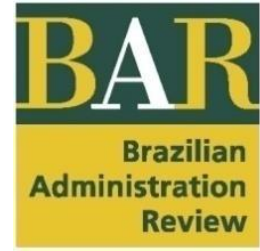

\title{
Reverse Knowledge Transfer in Multinational Companies: A Systematic Literature Review
}

Clarice Secches Kogut ${ }^{1}$

Renato Cotta de Mello ${ }^{1}$

Universidade Federal do Rio de Janeiro/Instituto COPPEAD de Administração ${ }^{1}$

Received 29 September 2016; received in revised form in 25 March 2017 (this paper has been with the authors for two revisions); accepted in 27 March 2017; first published online 10 April 2017. Editor's note. Mario H. Ogasavara served as Action Editor for this article. 


\begin{abstract}
The mainstream literature has focused on knowledge transfers from parent companies to subsidiaries, while paying less attention to knowledge created at the subsidiary level. But there is a growing trend to knowledge co-creation, and the responsibility of knowledge creation has shifted from headquarters to the corporation as a whole and its subsidiaries. Using a thorough systematic review over a 15 -year period in top-tier journals, this thematic analysis finds interesting literature gaps to be filled and proposes a theoretical framework that conceptualizes the reverse knowledge transfer as a complex process; moreover, we offer a detailed view on the phenomenon of reverse knowledge transfer, seeking to contribute to a better understanding of it and providing a basis to assist corporate managers in global strategic planning and knowledge management and scholars in future academic research in the field.
\end{abstract}

Key words: thematic analysis; reverse knowledge transfer; international competitive advantage; knowledge management; subsidiary headquarters relationship. 


\section{Introduction}

The knowledge transfer between headquarters and subsidiaries is an important research topic in International Business (IB) studies (Alharbi \& Singh, 2013). However, the mainstream literature has focused on knowledge transfers from parent companies to subsidiaries (Dunning, 2001; Johanson \& Vahlne, 1977, 2009; Rugman, 2006; Vahlne \& Johanson, 2014; Vernon, 1966, 1993), and not vice versa (from subsidiaries to parent company).

The literature on such bottom-up transfer, referred hereafter as reverse knowledge transfer (RKT), is still limited (Ambos, Ambos, \& Schlegelmilch, 2006; Criscuolo, 2009; Hakanson \& Nobel, 2001; J. Li, Strange, Ning, \& Sutherland, 2016; Tseng, 2015), in spite of its growing importance to the knowledge generation (Frost \& Zhou, 2005; Gupta \& Govindarajan, 2000; J. Li et al., 2016; Tseng, 2015) of multinational enterprises (MNE) and its contribution to global competitive advantage (Chung, 2014; Eden, 2009; Frost \& Zhou, 2005; Makela, Bjorkman, \& Ehrnrooth, 2009; Tseng, 2015).

In addition to being limited in terms of the number of studies, the RKT literature is also limited in breadth, with papers usually falling short of analyzing the phenomenon as thoroughly and holistically (Pérez-Nordtvedt, Kedia, Datta, \& Rashee, 2008) as possible, and often merely addressing a single aspect of the process. Thus, the literature has many gaps to be filled, and by failing to examine the company and the process as a whole, "the spread of innovation, technological, managerial and marketing advantages is not addressed" (Ietto-Gillies, 2005, p. 11).

Using a thorough systematic review of a 15 -year period, from 2001 to $2016^{(1)}$, in top tier journals, this present study finds interesting literature gaps to be filled and proposes a theoretical framework that conceptualizes the reverse knowledge transfer as a complex process with factors to be analyzed in detail such as the sender of knowledge (subsidiary), the receiver (parent), the direct and indirect mechanisms of knowledge transfer and the characteristics of the knowledge itself. In addition, the antecedents of the subsidiary and - most importantly - how the RKT benefitted the MNE are examined. In this work we intend to provide a detailed view of the phenomenon of reverse knowledge transfer, contributing to a better understanding of it and seeking to serve as a basis to assist corporate managers in global strategic planning and knowledge management and scholars in future academic research in the field.

To the extent that an understanding of how reverse knowledge transfer can benefit the parent company is interesting not only vis-à-vis internationalization but also vis-à-vis strategic management, we hope this paper to be all the more appealing. According to Autio (2005), most internationalization theories have tended to rely on either economic or organizational and behavioral theories; however, the internationalization context and its attendant theories have contributed little reciprocal insight to organizational and strategic theories. Autio therefore points to this as an important research gap and suggests empirical and theoretical academic works to be conducted "to better understand the sources and effects of the 'internationalization competitive advantage' as well as to articulate the practitioner implications of this potential effect" (Autio, 2005, p. 16).

This paper is organized as follows: second section provides a theoretical background on the importance of knowledge and knowledge management for IB and the subsidiary's respective role; third section explains the perceived research gap and how previous work has been framed. Fourth section explains the methodology used; fifth section discusses results and findings; and finally, sixth section concludes by listing some limitations and contributions of the research as well as possible avenues for future research. 


\section{Theoretical Background}

Multinationals are, above all, in the relentless pursuit of international competitive advantages, meaning advantages over competitors based on some exclusive strategic resource (Barney, 1991). The Resource-based View (RBV) argues that for a company to have a competitive advantage its resources need to be VRIS: valuable, rare, difficult to imitate and difficult to substitute, as per Penrose (1959) and Barney (1991), among other authors.

Expanding on that came the knowledge based view (KBV), with several authors arguing "knowledge has emerged as the most strategically-significant resource of the firm" (Grant, 1996, p. 375; J. H. Li, Chang, Li, \& Ma, 2014; Oliveira, 2007; Pérez-Nordtvedt, Mukherjee, \& Kedia, 2015). Even though authors from other school of thought may not be so assertive about that, it is a consensus in the literature that after the shift from industrial to a post-industrial age, that knowledge is the most critical resource to firms (Nonaka \& Takeuchi, 1995).

Accordingly, among the many benefits of internationalization for an organization, most scholars would agree that knowledge creation and sharing are important ones, so important, in fact, that noteworthy authors from several different schools in internationalization (Dunning, 2001; Johanson \& Vahlne, 1977, 2009; Oviatt \& MacDougall, 1994; Rugman, 2006; Vahlne \& Johanson, 2014; Vernon, $1966,1993)$ have frequently addressed the subject in their theories, paradigms and models. Although knowledge may not be explicitly central in some if not most discussions, it is important enough to garner attention, thus demonstrating its relevance and need for a better understanding of its mechanisms and flows in the context of multinational companies.

Figure 1 below summarizes the views of the main schools of internationalization as to where or with whom knowledge lies in the organization and its potential transferability, aiming not to contrast them but to show the importance of knowledge for internationalization theories in general.

\begin{tabular}{|c|c|c|c|c|}
\hline & \multicolumn{2}{|c|}{ Economic School } & \multicolumn{2}{|c|}{ Behavioral School } \\
\hline & $\begin{array}{l}\text { Product life } \\
\text { cycle } \\
\text {-Vernon } \\
(1966)\end{array}$ & $\begin{array}{l}\text { Other Economic } \\
\text { theories } \\
\text { - Rugman }\left(1975^{*}\right) \\
\text { - Dunning }\left(1977^{*}\right)\end{array}$ & $\begin{array}{l}\text { Uppsala Model } \\
\text { - Johanson andVahlne } \\
\text { (1977) }\end{array}$ & $\begin{array}{l}\text { International } \\
\text { entrepreneurship } \\
\text { - Oviatt and McDougall } \\
\text { (1994) }\end{array}$ \\
\hline $\begin{array}{l}\text { Knowledge } \\
\underline{\text { location }}\end{array}$ & $\begin{array}{l}\text { K tied to a } \\
\text { location } \\
\text { (location-bound) }\end{array}$ & $\begin{array}{l}\text { Tied to the firm } \\
\text { (non-location bound) }\end{array}$ & $\begin{array}{l}\text { Tied to a person- } \\
\text { experiential } \\
\text { (non-location } \\
\text { bound) }\end{array}$ & $\begin{array}{l}\text { Must not be tied } \\
\text { anywhere or to anyone } \\
\text { in the organization }\end{array}$ \\
\hline $\begin{array}{l}\text { Knowledge } \\
\text { transferability }\end{array}$ & $\begin{array}{l}\text { Difficult to } \\
\text { transfer }\end{array}$ & $\begin{array}{l}\text { Transferable from } \\
\text { parent to subs. in an } \\
\text { international expansion }\end{array}$ & $\begin{array}{l}\text { Transferable from person } \\
\text { (in parent) to person (in } \\
\text { subsidiary) - more } \\
\text { difficult }\end{array}$ & $\begin{array}{l}\text { Must flow within the } \\
\text { organization but not } \\
\text { outside it }\end{array}$ \\
\hline
\end{tabular}

Figure 1. Main Internationalization Theories and Their View on Knowledge and Knowledge Transferability

Source: prepared by authors. $(*)$ date of first paper.

In this paper, knowledge is assumed to be a firm-specific strategic resource, one that is valuable, rare and difficult to imitate or substitute (Barney, 1991; Cuervo-Cazurra \& Un, 2004; Loane \& Bell, 2006), such as any kind of innovation, technology, management techniques, capabilities, marketing and production skills that can be transferred from one location to another. 
As can be seen from Figure 1 above, most authors (Dunning, 2001; Johanson \& Vahlne, 1977, 2009; Rugman, 2006; Vahlne \& Johanson, 2014; Vernon, 1966, 1993) focused knowledge created at the parent company or headquarters level. It is reasonable to assume that this is because the main theories were conceived in periods preceding the current level of globalization and are rooted in the contexts of developed countries; therefore, they do not account for more recent phenomena such as emerging market multinationals or bi-directional information flows (Fleury \& Fleury, 2007).

A very interesting, useful and more recent theory that may help address the above issue (EM MNE) is the Springboard Perspective (Luo \& Tung, 2007; Petersen \& Ivarsson, 2015). With EM MNEs being less likely to seek cost minimization strategies, as they are usually already located in low-cost countries, they usually follow a market-seeking or asset-seeking strategy. Strategic assets include technology, know-how, R\&D facilities, human capital, brands, consumer bases, distribution channels, managerial expertise, and natural resources, all with the specific purpose of (a) strengthening their position at home, and (b) compensating any firm-level competitive disadvantages they may have. This perspective is thus of special interest to this study as it necessarily involves a RKT process. However, the springboard perspective does not specify any of the steps or actors in the process, stating only that "their resource commitment, especially investment size, is not necessarily a function of time, experience or learning" (Luo \& Tung, 2007, p. 491). Regarding knowledge and knowledge transferability specifically, which is the focus of this research, the springboard perspective recognizes only the importance and progressive nature of learning.

\section{Subsidiary knowledge: its relevance in internationalization theories}

Headquarters have been responsible for the bulk of a multinational's value creation and competitive advantages (Chandler, 1991; Ciabuschi, Dellestrand, \& Nilsson, 2015) and "subsidiaries have traditionally been perceived as receivers of knowledge and theorized as inferior to HQ on several dimensions, including questioning the stock and value of knowledge they possess" (Michailova \& Mustaffa, 2012, p. 389).

However, the subsidiaries are increasingly contributing to the company's value creation (Chung, 2014; Ciabuschi et al., 2015; Criscuolo, 2009; Eden, 2009; Frost \& Zhou, 2005; Makela et al., 2009). Cuervo-Cazurra and Un (2004) for example have stated that strategic, or advantageous, international resources that are firm-specific can derive not only from a parent company advantage but also from a subsidiary advantage or a multinational advantage.

Regarding knowledge specifically, despite not considering it at first, in his later works Dunning (2001) acknowledged that some endogenous variables related to knowledge, such as technological or organizational innovations, management changes, new marketing techniques and others, were relevant in creating a company's competitive advantage and that companies were "increasingly growing internationally to create or gain access to resources or capabilities which complement their core competencies" (Dunning, 2001, p. 183). In other words, multinationals apparently did learn from international operations and consequently improved their competitive positioning.

Thus, the environment is changing to a scenario in which knowledge flow is abundant, speed and cost of communication are higher and lower respectively, managerial experience is increasingly becoming international, and alternative governance mechanisms are emerging (Autio, 2005), giving rise to new forms of ventures.

One such form of new venture, as previously mentioned, is the EM MNE: "international companies that originated from emerging markets and are engaged in outward FDI, where they exercise effective control and undertake value-adding activities in one or more foreign countries" (Luo \& Tung, 2007, p. 482). EM MNEs expand rapidly and aggressively to overcome their latecomer disadvantages, which often lack of knowledge or expertise. In this sense, the subsidiary's knowledge is essential and strategic to overcoming the parent's deficiencies, which makes the KT process to parent company therefore essential and strategic too. A good example is the acquisition of Volvo Cars Corporation by Zheijiang Geely Holding in 2010 (Petersen \& Ivarsson, 2015). The fairly small and unknown Chinese 
company wanted to use Volvo's technology and famous brand to benefit locally and abroad. The plan was to exploit not only Volvo's products, but also its technologies and R\&D capabilities for development of Geely's own 2010 lineup (Petersen \& Ivarsson, 2015).

Needless to say, for a parent company to benefit from a subsidiary's knowledge, headquarters must be aware of it (Ciabuschi et al., 2015; Kumar, 2013). If headquarters is aware of its own and its subsidiaries' knowledge, it can better formulate corporate strategy and allocate resources. If, on the other hand, it doesn't know exactly what kind of knowledge it possesses and what kind it lacks, "its ability to control and contribute to value creation process is unclear" (Ciabuschi et al., 2015, pp. 44-45).

Similarly, some authors argue that the RKT is a persuasion process, with the subsidiary having to convince the parent of the value of its knowledge (Pérez-Nordtvedt et al., 2015).

\section{The Research}

Transfer of knowledge, streaming from headquarters to the subsidiaries (hierarchical direction), is the traditional direction of flow, as framed in most theories (Dunning, 2001; Johanson \& Vahlne, 1977, 2009; Rugman, 2006; Vahlne \& Johanson, 2014; Vernon, 1966, 1993). For this reason, the opposite flow (from subsidiary to parent company) is called reverse knowledge transfer (RKT). Other authors also refer to the RKT concept as reverse technology transfer (Belderbos, Van Roy, \& Duvivier, 2013; Criscuolo, 2009; Driffield, Love, \& Menghinello, 2010), reverse knowledge flow (Maehler, Curado, Pedroso, \& Pires, 2011), reverse transfer of practices (Chung, 2014) and akin.

We define a RKT as a process through which knowledge is transferred from a source that is affiliated (subsidiary) to the recipient (headquarters), and the recipient receives, assimilates and applies their knowledge in order to obtain a competitive advantage.

As demonstrated in the brief theoretical background developed, most studies have focused on the traditional flow, leaving a literature gap (Michailova \& Mustaffa, 2012), to be filled regarding the study of RKT. Moreover, the existing studies in RKT seem to be overly focused on why these transfers occur and what are the enabling mechanisms (the how).

RKT is a growing phenomenon that deserves special attention and that poses many questions; thus this paper aims to provide a review of what has been written on the subject in top journals over the past 15 years in a quest for answers and to discern research gaps. A theoretical framework is also proposed for analyzing such a complex process. This endeavor can be achieved through a thorough systematic analysis, as described in detail in the Method section below.

\section{Method}

The method chosen for conducting the literature analysis was a systematic review - a reliable, replicable and scientific method for conducting literature reviews (Petticrew \& Roberts, 2006). In the words of Petticrew and Roberts, a systematic review "explicitly aims to limit systematic error (bias), mainly by attempting to identify, appraise and synthesize all relevant studies (of whatever design) in order to answer a particular question (or set of questions)" (Petticrew \& Roberts, 2006, p. 9) and hence is suitable for this thematic analysis.

Only peer reviewed articles from top academic journals were included in the review in order to ensure the quality of the work. Please find below the list of journals included in this systemic survey, which yielded an average impact factor of 1.84 and an average $\mathrm{H}$ index of 62.1. Any other top academic 
journal that is not listed below is because no relevant article was found as per out filters described further down this section.

Table 1

Result of Systematic Literature Review Search by Journal

\begin{tabular}{lc}
\hline International Journals & Number of papers \\
\hline Management International Review (MIR) & 12 \\
Journal of International Business Studies (JIBS) & 10 \\
Journal of Knowledge Management & 7 \\
Thunderbird International Business Review & 4 \\
International Journal of Human Resource Management & 3 \\
Industrial and Corporate Change & 3 \\
Critical Perspectives of International Business & 2 \\
Journal of Management Studies & 1 \\
Knowledge Management Research \& Practice & 1 \\
Management \& Organization Review & 1 \\
Journal of Tech Management \& Innovation & 1 \\
The American Economic Review & 1 \\
Journal of Intelligent Manufacturing & 1 \\
Foresight & 1 \\
Expert Systems & 1 \\
Review of Policy Research & 1 \\
Journal of World Business & 1 \\
Service Industries Journal & $\mathbf{5 2}$ \\
\hline TOTAL & 1 \\
\hline Note. Sour: & 1 \\
\hline
\end{tabular}

Note. Source: prepared by the authors.

Furthermore, a fifteen-year period, from 2001 to $2016^{(2)}$, was defined in order to have a long enough period to ensure a solid review but not so long that outdated material would be included.

Finally, only articles written in English were reviewed, in both EBSCO and PROQUEST databases. Keywords searched were reverse knowledge transfer OR reverse knowledge flow OR reverse technology transfer AND Internationalization AND subsidiaries. The same searches were performed with British spelling (i.e., internationalisation instead of internationalization) in order not to miss any potentially important article.

The searches yielded 154 articles, which were then manually filtered for repeated articles and scope. In this manual verification and selection for scope, a two-step process was followed. First, only title and abstract were read and a few articles were already discarded for not being related to Reverse Knowledge Transfer. In a second step, all articles were fully read in order to see how they approached the RKT phenomenon. Some were again not related to the RKT as the title and abstract might have led us to believe and were discarded. The remainders were all fully analyzed in the main section of the article. 
Table 2

Result of Systematic Literature Review Search

\begin{tabular}{lcccc}
\hline Research Database & $\begin{array}{c}\text { Search (date and } \\
\text { journal quality } \\
\text { filters) }\end{array}$ & Repeated articles & $\begin{array}{c}\text { Qualitative filter } \\
\text { (scope) }\end{array}$ & Final \\
\hline EBSCO & 91 & -47 & -30 & 61 \\
PROQUEST & 60 & -22 & 38 \\
\hline Total & $\mathbf{1 5 4}$ & & & -47 \\
\hline
\end{tabular}

Note. Source: prepared by the authors.

As can be seen from Table 2 above, only 52 articles remained after quality, date, and duplication search/scope filters were applied. Some additional papers that did not directly come from our systematic search, but were referenced in those in our search may also be cited in the results section below due to their relevance to the theme. Discussion of the papers follows in the next section.

\section{Results}

As already mentioned, with very few exceptions (Nair, Demirbag, \& Mellahi, 2015; PérezNordtvedt et al., 2008; Tseng, 2015), most studies tend not to analyze the RKT as a process, but to focus on a specific aspect of the process at a time, such as how or why the transfer occurs. However, the RKT phenomenon is a full process, and thus should be analyzed with all of its parts and contexts.

Gupta and Govindarajan (2000), Pérez-Nordtvedt, Kedia, Datta and Rashee (2008) and Tseng (2015), to cite a few, consider as factors influencing the degree of knowledge (a) flows from the sender (source unit), (b) to the receiver (target unit), (c) the transmission per se (formal and informal mechanisms) and (d) the knowledge characteristics (mainly complexity and tacitness). Figure 2 below summarizes a typical knowledge flow process. In an RKT process, the target unit will be the headquarters and the source unit would be the subsidiary holding the knowledge to be transferred.

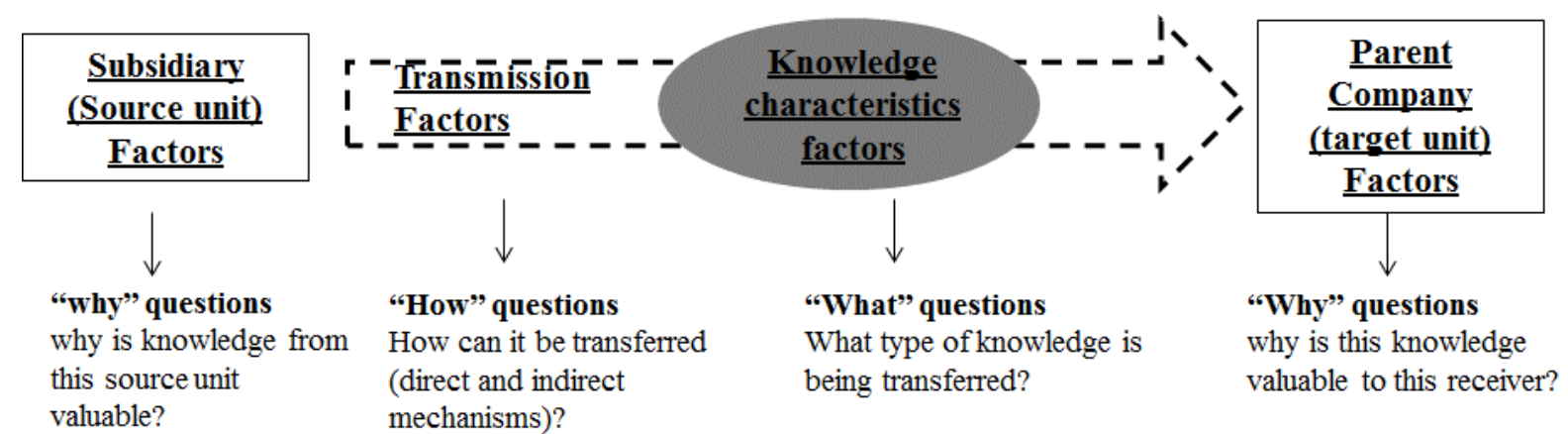

Figure 2. MNC's Internal Knowledge Flow as a Transferring Process

Source: Prepared by the authors based on Gupta, A. K., \& Govindarajan, V. (2000). Knowledge flows within multinational corporations. Strategic Management Journal, 21(4), 473-496. http://dx.doi.org/10.1002/(SICI)10970266(200004)21:4<473::AID-SMJ84>3.0.CO;2-I; Pérez-Nordtvedt, L., Kedia, B. L., Datta, D. K., \& Rashee, A. A. (2008). Effectiveness and efficiency of cross-border knowledge transfer: an empirical examination. Journal of Management Studies, 45(4), 714-744. http://dx.doi.org/10.1111/j.1467-6486.2008.00767.x; Tseng, C. (2015). Determinants of MNC's knowledge inflows to subsidiaries: a perspective on internalization advantages. Management International Review, 55(1), 119-150. http://dx.doi.org/10.1007/s11575-014-0230-7

But "the majority of studies on knowledge transfer focus on either the relationship between the source and the recipient, the recipient itself, the source itself or the type of knowledge being transferred. 
With few exceptions ..., research has failed to simultaneously examine all of these antecedents" (PérezNordtvedt et al., 2008, p. 715), indicating a literature gap.

Our analysis is consistent with the position of Pérez-Nordtvedt et al. (2008), as can be seen in Figure $3^{(3)}$, indicating that few studies analyze RKT as a full process. However, we go a little further, we can incorporate two additional stages to the process: the pre-transfer, which pertains to the circumstances under which the knowledge was created on the subsidiary; and the post-transfer consequences to the parent company and the MNE as a whole.

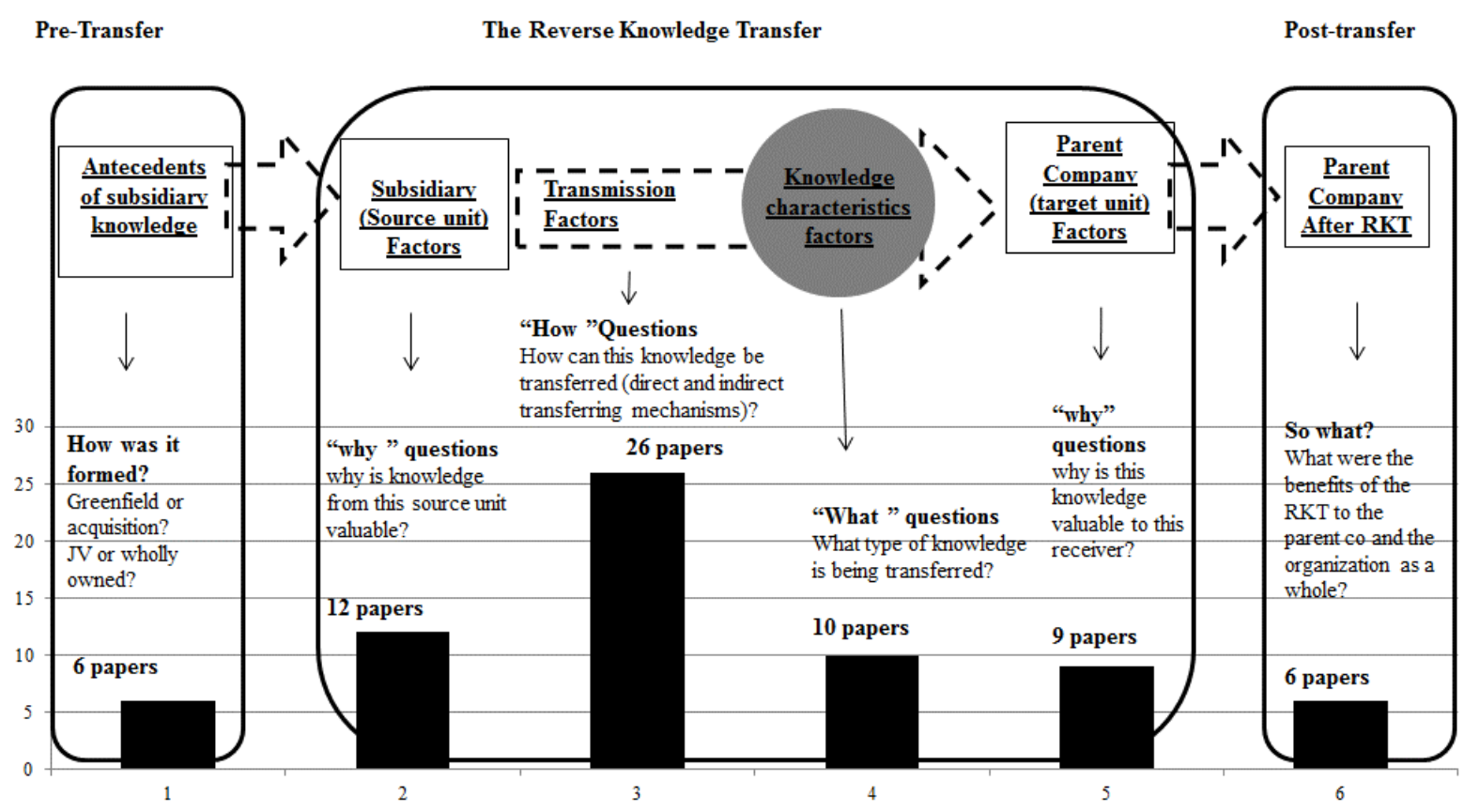

Figure 3. MNC's Internal Knowledge Flow Complete Transferring Process Source: Prepared by the authors.

\section{Pre-transfer aspects: antecedents to knowledge of the subsidiary}

Regarding the pre-transfer factors influencing the RKT, the most cited aspects are relative to the subsidiary's entry mode: Greenfield or acquisition and joint venture (JV) or wholly-owned subsidiary. "knowledge transfer is pre-determined by entry-strategy and the conditions under which this is made. The ownership entry choice may lock foreign firms into constraints from which it is difficult to escape" (Buckley, Clegg, \& Tan, 2003, p. 67).

If the MNE entered the country through an acquisition, it is more likely that it has a stock of knowledge ready to be transferred to headquarters (Gupta \& Govindarajan, 2000; Najafi-Tavani, Axèle, \& Sinkovics, 2012a), usually one of interest to the parent company, and sometimes even the very reason for the acquisition (J. Li et al., 2016). On the other hand, an acquired company has a different culture and set of values and routines, making the subsequent transfer of knowledge more challenging than among units of the same company (Öberg, 2013). The headquarters in this case has the challenge of implementing its dominant business logic while leaving enough space to build a unified social community that allows for the existent knowledge at the acquired company to be transferred (Verbeke, 2010).

A greenfield subsidiary, on the other hand, usually depends more on the parent company's knowledge base, which tends to indicate a smaller stock of knowledge to transfer to parent company (RKT), fact which also facilitates the knowledge transfer process (Najafi-Tavani et al., 2012a). 
The transfer of knowledge in an alliance or JV, for example, adds another layer of complexity on top of those already existing in the process: one involving trustworthiness and willingness to take risk among the parties (Becerra, Lunnan, \& Huemer, 2008), as despite the usual parent-subsidiary relationship there is an additional parent-subsidiary relationship and the parent-parent relationship to be managed, all of which operating under a different culture and set of practices and thus making the transfer of knowledge potentially more difficult. Buckley, Clegg and Tan (2003) claim studies are lacking with respect to JV and wholly-owned subsidiaries in relation to knowledge transfer, but also assert that the choice of entry mode is unlikely to be neutral. Chung (2014) corroborates this view, stating that the wholly-owned subsidiaries can significantly help in the objective of reverse transfer of practices.

\section{The RKT itself: source, transmission factors, knowledge characteristics and recipient analysis}

As previously mentioned, our study confirms that most studies on RKT can be separated into why RKT occur and how these transfer flows occur, leaving unanswered other types of questions (Becerra et al., 2008; Najafi-Tavani et al., 2012b). For a complete list on which paper focuses on which part of the process, please refer to Appendix.

\section{“Why” questions: source and recipient analysis}

When analyzing the why of an RKT, studies tend to focus on locational aspects of both sender (subsidiary) and receiver (parent) of the knowledge, supported more by the economic theories of internationalization. However, as discussed below, the main topics are not necessarily economic related which raises the question as to whether a different perspective might have been more suitable.

Main topics of research found in relation to the sender, or, in the case of RKT, the subsidiary (i.e., why knowledge from this specific subsidiary is valuable) included (a) the growing trend and benefits for the internationalization of firm R\&D (Criscuolo, 2009; Criscuolo \& Narula, 2007; D'Agostino \& Santangelo, 2012; Di Minin \& Zhang, 2010; Massini \& Miozzo, 2012; Moncada-Paternò-Castello, Vivarelli, \& Voigt, 2011; Sanna-Randaccio \& Veugelers, 2007) and (b) discussions relating knowledge creation to the level of network embeddedness of the subsidiary (Hakanson \& Nobel, 2001; JiménezJiménez, Martínez-Costa, \& Sanz-Valle, 2014; Najafi-Tavani et al., 2012b; Williams \& Ecker, 2011).

Additionally, and related to those topics, spillover effects, that is, benefits accrued from proximity to companies of superior knowledge, were mentioned by other authors as a benefit and reason for having an international presence (Griffith, Harrison, \& Van Reenen, 2006; Liu, Lu, \& Choi, 2014). Taken as a whole, the above mentioned topics and authors refer, in different ways and through different concepts, to a parent company engaging in an RKT process to benefit from knowledge to which its subsidiary had access by virtue of being in a certain location, with certain players or in a certain context of superior or different knowledge stock, knowledge that the parent company would not otherwise have access to.

Finally, other interesting findings are that RKT (a) is more likely to occur when the subsidiary is located in an economically developed country (Ambos et al., 2006) and (b) tends to vary with size and age of the subsidiary (Bezerra, Borini, \& Maclennan, 2015).

The second why question in the RKT depicted in Figure 4 above refers to why the parent company needs this kind of knowledge, or why is this knowledge valuable to this specific parent company. The salient topics found on this receiver side of the RKT process were related either to a catch-up strategy and latecomer perspective of emerging market companies or to a knowledge-based view as performance enhancers.

Many scholars studying EM enterprises see EM MNEs as increasingly engaging in springboarding and knowledge-seeking FDI to compensate for their deficiencies (Eden, 2009; J. Li et al., 2016; Luo \& Tung, 2007), which may include liability of foreignness or third-world image (Nair $e t$ 
al., 2015), and, most importantly, competitive weaknesses compared to global leaders (Deng, 2013). Thus, RKT is an important ally in this catch-up strategy (Awate, Larsen, \& Mudambi, 2015; J. Li et al., 2016), for it enables knowledge to flow from the subsidiary to the headquarters and to the rest of the corporation. This, in turn, enables the MNCs to obtain competitive advantages by combining local knowledge with their own technological and management capabilities (Chung, 2014; Tseng, 2015) and accrue the consequent benefits of it. Indeed, Sofka (2008, p. 786) claims the globalization of knowledge in the MNCs "is in fact a combination of investments into absorptive capacities, international experience and domestic scarcities".

Several authors appear to conflate the two why questions, posing the question in terms of why the knowledge created at one specific subsidiary is valuable to a specific parent company. Indeed, Belderbos, Lokshin and Sadowski (2015) do so, stating that "the roles of domestic and foreign R\&D depend on the relative position of the home country with respect to the global technology frontier and the related relative opportunities for knowledge sourcing abroad" (p. 491). In other words, the value of RKT will be apparent when the parent company lags behind vis-à-vis certain knowledge and has the opportunity to acquire it from a subsidiary located in a host country that is more competitive than the home country (Nair et al., 2015).

\section{'How' questions: transmission enhancers and restrainers}

When analyzing how RKT progresses, most studies focus on the direct and indirect mechanisms that may invigorate or sabotage a successful transfer, therefore giving a more human resources' related aspect to the research.

In this regard, important topics discerned were the use of binding mechanisms or social interactions among employees to facilitate the transmission process. Studies focused on (a) general social interaction to promote overall communication and integration (Ambos et al., 2006; Chung, 2014; Criscuolo, 2009; Frost \& Zhou, 2005; Noorderhaven \& Harzing, 2009; Pérez-Nordtvedt et al., 2008; Verbeke, 2010; Zaragoza-Sáez \& Claver-Cortés, 2011); or, more specifically (b), the use of expatriates (Bruning, Bebenroth, \& Pascha, 2011; Ghauri \& Park, 2012; Huang, Chiu, \& Lu, 2013; Makela et al., 2009; Najafi-Tavani et al., 2012b; Vance, Andersen, Vaiman, \& Gale, 2014; Zaragoza-Sáez \& ClaverCortés, 2011); (c) rotation jobs (Criscuolo \& Narula, 2007; Hakanson \& Nobel, 2001; Minbaeva, Pedersen, Björkman, \& Fey, 2014); or (d) returnees to the home country (Liu et al., 2014).

Additionally, (a) having similar cultural aspects and a shared vision or logic (Betz, Oberweis, \& Stephan, 2014; Colakoglu, 2012; Criscuolo \& Narula, 2007; Ghauri \& Park, 2012; Nair et al., 2015; Najafi-Tavani et al., 2012a; Öberg, 2013; Verbeke, 2010); (b) creating specific organizational structures such as project or joint R\&D teams (Criscuolo \& Narula, 2007; Lichtenthaler, 2010; Minbaeva et al., 2014); (c) having a more integrated business in general, with strategy and practices aligned (Hakanson \& Nobel, 2001; J. H. Li et al., 2014; Najafi-Tavani et al., 2012b); and, finally, (d) having formal rules and the necessary information and communication tools well established (Chung, 2014; Criscuolo, 2009; Zaragoza-Sáez \& Claver-Cortés, 2011) seem to improve the RKT process in the studies analyzed.

In addition to the above mechanisms, several papers highlighted the importance of the parent company valuing and being willing to receive the transfer of knowledge, a concept also referred to as having willingness to learn or learning intent (Belderbos et al., 2013; Pérez-Nordtvedt et al., 2008). Relatedly, some authors adopt the term absorptive capacity (Ambos et al., 2006; Criscuolo \& Narula, 2007; J. Li et al., 2016; Sofka, 2008; Vance et al., 2014), which Frost and Zhou (2005) define as the ability to recognize the value of new knowledge, assimilate it, and apply it. In contrast, Minbaeva, Pedersen, Björkman and Fey (2014) define absorptive capacity as having the motivation, ability and opportunity to absorb knowledge.

On the other end of the spectrum, willingness to transfer knowledge has also been tackled by authors such as Huang, Chiu and Lu (2013), Najafi-Tavani et al. (2012a) and Criscuolo and Narula (2007). Indeed, it turns out that subsidiaries or executives may be unwilling to transfer their knowledge 
due to fear of losing autonomy, information monopoly (Criscuolo \& Narula, 2007), and their relative power inside the organization (Alharbi \& Singh, 2013).

Finally, a culture of sharing (Huang et al., 2013; Minbaeva et al., 2014) and trust building (Chung, 2014; Huang et al., 2013; J. H. Li et al., 2014; Najafi-Tavani et al., 2012b) is believed to be beneficial not only to one specific process of RKT, but to the process of knowledge creation of the MNE as a whole. Kumar (2013) also observes that managerial attention during the process is crucial to success.

\section{'What' questions: what kind of knowledge is being transferred?}

In line with the knowledge-based view (KBV) proponents, Pérez-Nordtvedt et al. (2008) claim knowledge value, rarity and non-substitutability are determinants of attractiveness for RKT.

Yet, despite attractiveness, another dimension that should be analyzed in an RKT process is the knowledge transferability; and it is on this last dimension that most authors analyzed in this paper have focused their efforts. According to Kotabe, Dunlap-Hinkler, Parente and Mishra (2007), knowledge transferability should be analyzed according to its tacitness, specificity and complexity.

Nair, Demirbag and Mellahi (2015) focus on the importance of analyzing knowledge complexity, claiming that it deals with "the comprehension of the knowledge and is also closely associated with the width that the knowledge spans (Grant, 1996). Hence, knowledge could prove to be more complex especially when it spans across multiple domains of expertise" (Nair et al., 2015, p. 284). The authors also add that the complexity of knowledge contributes to increasing a characteristic that several other authors (Chung, 2014; Liu et al., 2014; Pérez-Nordtvedt et al., 2015) attribute to knowledge: its stickiness, or its difficulty to be transferred.

But most authors analyze knowledge according to its tacitness (Choi, Cheng, Hilton, \& Russell, 2005; Johnson, 2007), some focusing on differentiating the two poles: explicit and tacit knowledge (Becerra et al., 2008; Buckley et al., 2003; Jaw, Wang, \& Chen, 2006). Tacit knowledge is defined as knowledge that cannot be codified or expressed explicitly and is rooted in everyday practices, routines, culture and values (Nonaka, 1994; Noorderhaven \& Harzing, 2009). Explicit knowledge, on the other hand, is codifiable and expressed in data, manuals, and the like. However, even explicit sources of knowledge have a tacit component, as tacit knowledge assists in explaining explicit knowledge (Buckley et al., 2003; Jaw et al., 2006).

Tacit knowledge is considered much more difficult to transfer, since it is more difficult to teach (Hakanson \& Nobel, 2001) and requires a high degree of trustworthiness (Becerra et al., 2008; Noorderhaven \& Harzing, 2009). On the other hand, tacit knowledge is more difficult to imitate, thus rendering it more attractive (Pérez-Nordtvedt et al., 2008) and a source of competitive advantage to the firm (Becerra et al., 2008).

It is worth noting that even when the type of knowledge being transferred was not the focus of their research, several authors emphasized or mentioned the general tacit nature of knowledge and the consequent challenges of transferring it (Hakanson \& Nobel, 2001; Huang et al., 2013; Najafi-Tavani et al., 2012a; Sofka, 2008; Zaragoza-Sáez \& Claver-Cortés, 2011).

\section{Post-transfer: what happens after the RKT is complete?}

Some papers do focus on the performance effects of RKT or the benefits from knowledge transfer, as Figure 4 illustrates (Alharbi \& Singh, 2013; Chung, 2014; Kotabe, Dunlap-Hinkler, Parente, \& Mishra, 2007; Jaw et al., 20016; J. H. Li et al., 2014; Pérez-Nordtvedt et al., 2015). However, such studies are small in number compared to those focusing on the process per se, which is quite surprising considering that "the motivations of an MNC to conduct knowledge inflows depends on the extent of the benefits that the MNC will obtain after transferring knowledge to its subsidiaries" (Tseng, 2015, p. 121). 
The main benefits listed by authors are (a) knowledge creation and development of new products and technologies (Ambos et al., 2006; Hakanson \& Nobel, 2001); (b) coordination of a global strategy (Eden, 2009); (c) improvement of flow of communication (Kotabe et al., 2007); or (d) all of the foregoing (Chung, 2014; Kotabe et al., 2007).

Michailova and Mustaffa (2012) and Tseng (2015) noted though that when it comes to analyzing the benefits gained by the knowledge flows, studies don't usually analyze it from the MNE level, of how much did the knowledge flow help the MNE to reach its objectives and goals on a global level.

Some empirical studies, mainly based on quantitative methods, attempt to discern a relationship between RKT and firm performance (Alharbi \& Singh, 2013; Jaw et al., 2006; Kotabe et al., 2007; Pérez-Nordtvedt et al., 2015). The problem is how to measure these benefits, their effect on firm performance, and how exactly did the RKT contribute to performance, especially since "a large part of the benefits a subsidiary generates tends to be non-financial in nature, and thus difficult to quantify" (Alharbi \& Singh, 2013, p. 297).

Pérez-Nordtvedt, Mukherjee and Kedia (2015), for example, relate RKT effectiveness and efficiency positively to performance, defining effectiveness as achieving the desired outcome, and efficiency as achieving the desired outcome within the desired timeframe and cost. But when it comes to the definition of performance and how to measure it, authors resorted to a perceptual measure based on answers to surveys in a manner similar to previous works (Alharbi \& Singh, 2013). However, as previously stated, there is no consensus when it comes to measuring performance in KTs. For example, J. H. Li, Chang, Li and Ma (2014) suggest organizational performance as a proxy for the performance generated by the KT, while Belderbos, Van Roy and Duvivier (2013) were more specific in their research and related international KT to productivity growth.

Kotabe et al. (2007), on the other hand, consider only performance in innovation and raise the issue that cross-national KT may not always be beneficial, with the relationship between KT and innovative performance being "nonlinear, comprising a portion of expansionary growth where incremental costs can eventually exceed incremental benefits" (Kotabe et al., 2007, p. 263).

Finally, Ambos, Ambos and Schlegelmilch, 2006 found that while RKT are surely beneficial to headquarters, "the quantity of knowledge inflows is by no means equal to the benefit... research has to consider the value of the knowledge transferred" (Ambos et al., 2006, p. 306). J. Li et al. (2016) also add to that the quality of existing knowledge stock and personnel that will make use of the knowledge at parent level as important determinants of the benefits accrued from the RKT.

\section{Conclusion}

Historically, most researchers working in traditional theories of internationalization (Dunning, 2001; Johanson \& Vahlne, 1977, 2009; Rugman, 2006, Vahlne \& Johanson, 2014; Vernon, 1966, 1993) have focused on the knowledge flow from parent companies to subsidiaries, not giving as much attention to knowledge created at the subsidiary level, perceived as somewhat inferior to headquarters' (Michailova \& Mustaffa, 2012).

But, as demonstrated in this thematic analysis, there is a growing trend to knowledge co-creation, and the responsibility of knowledge creation has for some time been shifting from headquarters to the corporation as a whole and to its subsidiaries (Chung, 2014; Eden, 2009; Frost \& Zhou, 2005; Gupta \& Govindarajan, 2000; Makela et al., 2009), thus giving rise to the phenomenon of reverse knowledge transfer. This phenomenon is particularly important to and present in EM-MNEs as latecomers with a catch-up strategy (Ambos et al., 2006; Awate et al., 2015; Eden, 2009; Nair et al., 2015). Even so, many studies still originate from or focus on MNEs from developed countries (Buckley et al., 2003; Nair et $a l ., 2015)$, leaving a gap in the literature. Scholars from China and India have started to address this gap, 
but other emerging regions of the globe, such as Brazil and other countries in Latin America, have yet to do so (Nair et al., 2015, 2015; Oliveira, 2007, 2012).

It bears repeating that although the springboard perspective (Luo \& Tung, 2007) appears to be a suitable theoretical base for studies in EM MNE, it has thus far seen little use in studies of RKT, even in those specifically focused on emerging markets.

Our main conclusion from this thematic analysis is that reverse knowledge transfer is a complex process, and as such should be analyzed in terms of all of its components and its broader context. Figure 4 outlines the theoretical framework.

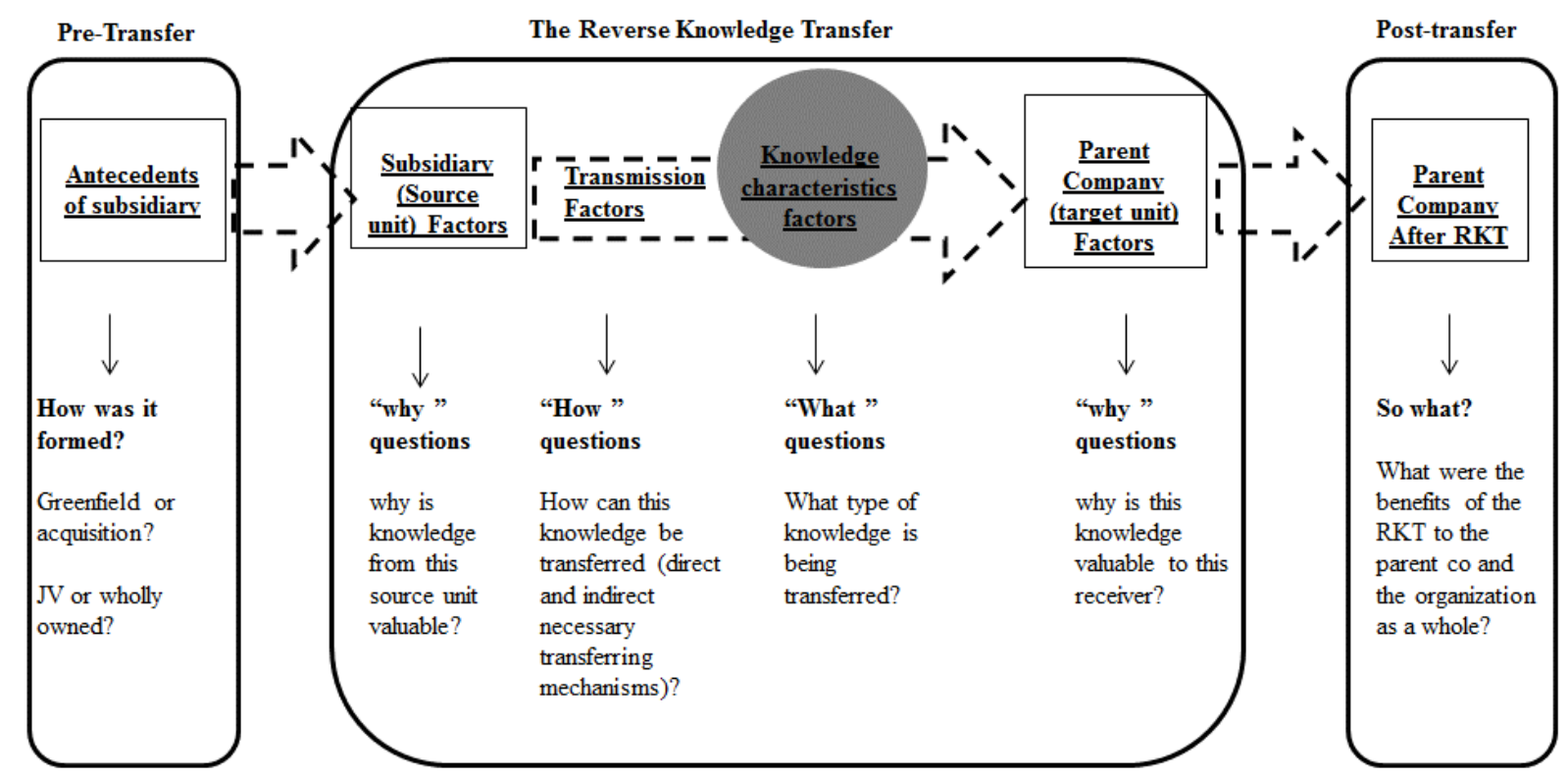

Figure 4. MNC's Internal Knowledge Flow Complete Transferring Process

Source: Prepared by the authors.

It is reasonable to assume that RKT is not actually a linear process, but one that is socially complex as well as reciprocal (Choi et al., 2005), whereby the subsidiary and headquarters are constantly interacting and mutually exchanging knowledge and information, both tacit and explicit.

However, most authors studying the phenomenon have focused on specific aspects of the process, overlooking the wider view (Pérez-Nordtvedt et al., 2008). Many have focused on the why of RKT or on the how of better knowledge transfer to the detriment of analyzing the process as a whole, including the antecedents of knowledge creation and, above all, the outcome of RKT, which is the most important part and yet one of the less researched. After all, although KT may be yet another process, one must emphasize the positive effect that the knowledge has on the recipient (J. H. Li et al., 2014), otherwise the transfer is pointless. J. H. Li et al. summed it up succinctly: "Only when knowledge is understood, assimilated and used for creating value, can highly-efficient knowledge transfer occur" (J. H. Li et al., 2014, p. 280).

Finally, our study corroborates with Michailova and Mustaffa's (2012), in showing that most studies are based on quantitative methods (mainly surveys); thus, another avenue for future research could be using case studies and more qualitative methods to understand this complex and contemporary phenomenon (Yin, 1994). 


\section{Limitations of the study}

We understand that, despite our efforts towards a systematic analysis, our filters (dates, journals, languages, sources and databases) prevented us from doing a complete and exhaustive literature review on the subject. However, by providing complete disclosure on our metrics, we have sought to produce work that is as reliable and replicable as possible.

Also, as stated in the conclusion section above, we acknowledge that our theoretical framework is a simplification of reality, with the RKT process being broken down into specific and divisible parts for illustration and analytic purposes only.

\section{Contributions}

This paper aims to make both practical and academic contributions. For practitioners, we sought to render the reverse knowledge transfer process clearer by breaking it down into component parts and aspects, thereby providing a comprehensive understanding of its complexity. Additionally, we hope that the work can contribute to the preparation of executives within MNE vis-à-vis knowledge management and how it can affect global strategies. To aid current and future academic work, we have inventoried and synthesized all relevant papers published in the target 15-year period $\left(2001-2016^{(4)}\right)$, which we believe is a reliable reference for further studies to address gaps and possible avenues of research.

\section{Notes}

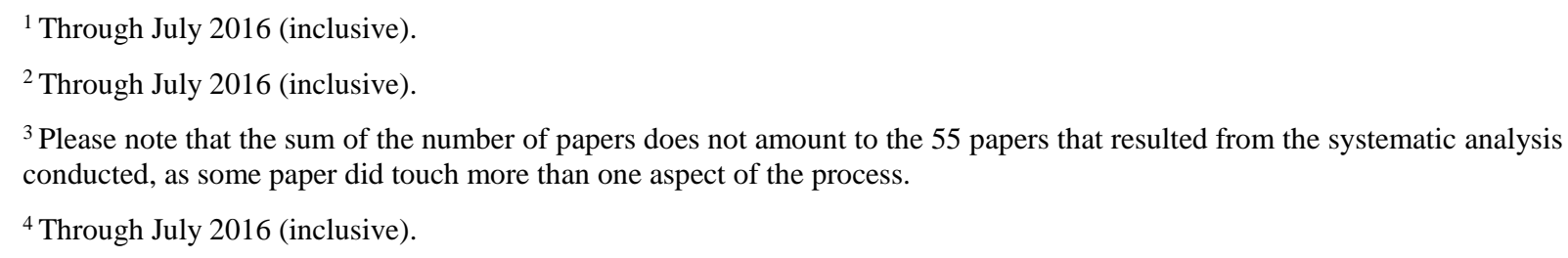

\section{References}

Alharbi, J., \& Singh, S. (2013). Knowledge transfer, controls, and performance of MNE subsidiaries in the Kingdom of Saudi Arabia. Foresight, 15(4), 294-306. http://dx.doi.org/10.1108/FS-04-20120021

Ambos, T. C., Ambos, B., \& Schlegelmilch, B. B. (2006). Learning from foreign subsidiaries: an empirical investigation of headquarters' benefits from reverse knowledge transfers. International Business Review, 15(3), 294-312. http://dx.doi.org/10.1016/j.ibusrev.2006.01.002

Autio, E. (2005). Creative tension: the significance of Ben Oviatt's and Patricia McDougall's article 'toward a theory of international new ventures'. Journal of International Business Studies, 36(1), 9-19. http://dx.doi.org/10.1057/palgrave.jibs.8400117

Awate, S., Larsen, M., \& Mudambi, R. (2015). Accessing vs sourcing knowledge: a comparative study of $\mathrm{R} \& \mathrm{D}$ internationalization between emerging and advanced economy firms. Journal of International Business Studies, 46(1), 63-86. http://dx.doi.org/10.1057/jibs.2014.46

Barney, J. (1991). Firm resources and sustained competitive advantage. Journal of Management, 17(1), 99-120. http://dx.doi.org/10.1177/014920639101700108 
Becerra, M., Lunnan, R., \& Huemer, L. (2008). Trustworthiness, risk, and the transfer of tacit and explicit knowledge between alliance partners. Journal of Management Studies, 45(4), 691-713. http://dx.doi.org/10.1111/j.1467-6486.2008.00766.x

Belderbos, R., Lokshin, B., \& Sadowski, B. (2015). The returns to foreign R\&D. Journal of International Business Studies, 46(4), 491-504. http://dx.doi.org/10.1057/jibs.2014.63

Belderbos, R., Van Roy, V., \& Duvivier, F. (2013). International and domestic technology transfers and productivity growth: firm level evidence. Industrial \& Corporate Change, 22(1), 1-32. https://doi.org/10.1093/icc/dts012

Betz, S., Oberweis, A., \& Stephan, R. (2014). Knowledge transfer in offshore outsourcing software development projects: an analysis of the challenges and solutions from German clients. Expert Systems, 31(3), 282-297. http://dx.doi.org/10.1111/exsy.12005

Bezerra, M. A., Borini, F. M., \& Maclennan, M. L. F. (2015). Reverse transfers of innovation and national development: evidence from Brazilian subsidiaries. Journal of Technology Management \& Innovation, 10(4), 1-8. http://dx.doi.org/10.4067/S0718-27242015000400001

Bruning, N. S., Bebenrothb, R., \& Pascha, W. (2011). Valuing Japan-based German expatriate and local manager's functions: do subsidiary age and managerial perspectives matter. The International Journal of Human Resource Management, 22(4), 778-806. http://dx.doi.org/10.1080/09585192.2011.555123

Buckley, P., Clegg, J., \& Tan, H. (2003). The art of knowledge transfer: secondary and reverse transfer in China's telecommunications manufacturing industry [Special Issue]. Management International Review, 43(2), 67-93. http://dx.doi.org/10.1007/978-3-322-90995-4_5

Chandler, A. D. (1991). The functions of the HQ unit in the multibusiness firm. Strategic Management Journal, 12(S2), 31-50. http://dx.doi.org/10.1002/smj.4250121004

Choi, C. J., Cheng, P., Hilton, B., \& Russell, E. (2005). Knowledge governance. Journal of Knowledge Management, 9(6), 67-75. http://dx.doi.org/10.1108/13673270510630303

Chung, L. (2014). Headquarters' managerial intentionality and reverse transfer of practices. Management International Review, 54(2), 225-252. http://dx.doi.org/10.1007/s11575-013-0192-1

Ciabuschi, F., Dellestrand, H., \& Nilsson, A. (2015). Value generation in the multinational corporations. In A. Verbeke, R. van Tulder \& R. Drogendijk (Eds.), The future of global organizing - progress in international business research (Vol. 10, pp. 39-56). Bingley, UK: Emerald Group Publishing Limited.

Colakoglu, S. (2012). Shared vision in MNE subsidiaries: the role of formal, personal, and social control in its development and its impact on subsidiary learning. Thunderbird International Business Review, 54(5), 639-652. http://dx.doi.org/10.1002/tie.21490

Criscuolo, P. (2009). Inter-firm reverse technology transfer: the home country effect of R\&D internationalization. Industrial \& Corporate Change, 18(5), 869-899. https://doi.org/10.1093/icc/dtp028

Criscuolo, P., \& Narula, R. (2007). Using multi-hub structures for international R\&D: organisational inertia and the challenges of implementation. Management International Review, 47(5), 639-660. http://dx.doi.org/10.1007/s11575-007-0038-9

Cuervo-Cazurra, A., \& Un, C. (2004). Firm-specific and non-firm-specific sources of advantage in international competition. In A. Ariño, P. Ghemawat, \& J. Ricart (Eds.), Creating value through international strategy (pp. 78-94). London: Palgrave Macmillan. 
D’Agostino, L. M., \& Santangelo, G. (2012). Do overseas R\&D laboratories in emerging markets contribute to home knowledge creation? Management International Review, 52(2), 251-273. http://dx.doi.org/10.1007/s11575-012-0135-2

Deng, P. (2013). Chinese outward direct investment research: theoretical integration and recommendations. Management \& Organization Review, 9(3), 513-539. http://dx.doi.org/10.1111/more.12030

Di Minin, A., \& Zhang, J. (2010). An exploratory study on international R\&D strategies of Chinese companies in Europe. Review of Policy Research, 27(4), 433-455. http://dx.doi.org/10.1111/j.1541-1338.2010.00450.x

Driffield, N., Love, J. H., \& Menghinello, S. (2010). The multinational enterprise as a source of international knowledge flows: direct evidence from Italy. Journal of International Business Studies, 41(2), 350-359. http://dx.doi.org/10.1057/jibs.2009.57

Dunning, J. H. (1977). Trade, location of economic activity and the multinational enterprise: a search for an eclectic approach. In B. Ohlin, P.-O. Hesselborn, \& P. M. Wijkman (Eds.), The international allocation of economic activity: proceedings of a nobel symposium held at Stockholm (pp. 395-418.). London: Palgrave Macmillan Limited. https://doi.org/10.1007/978-1349-03196-2_38

Dunning, J. H. (2001). The eclectic (OLI) paradigm of international production: past, present and future. International Journal of the Economics of Business, 8(2), 173-190. http://dx.doi.org/10.1080/13571510110051441

Eden, L. (2009). Letter from the Editor-in-Chief: reverse knowledge transfers, culture clashes and going international. Journal of International Business Studies, 40(2), 177-180. http://dx.doi.org/10.1057/jibs.2008.98

Fleury, A., \& Fleury, M. (2007). Internacionalização das empresas brasileiras: em busca de uma abordagem teórica para os late movers. In A. Fleury \& M. T. L. Fleury (Orgs.), Internacionalização e os países emergentes (pp. 3-13). São Paulo: Atlas.

Frost, T. S., \& Zhou, C. (2005). R\&D co-practice and 'reverse' knowledge integration in multinational firms. Journal of International Business Studies, 36(6), 676-687. http://dx.doi.org/10.1057/palgrave.jibs.8400168

Ghauri, P. N., \& Park, B. (2012). The impact of turbulent events on knowledge acquisition. Management International Review, 52(2), 293-315. http://dx.doi.org/10.1007/s11575-012-0136-1

Grant, R. M. (1996). Toward a knowledge based theory of the firm. Strategic Management Journal, 17(S2), 109-122. http://dx.doi.org/10.1002/smj.4250171110

Griffith, R., Harrison, R., \& Van Reenen, J. (2006). How special is the special relationship? Using the impact of U.S. R\&D spillovers on U.K. Firms as a test of technology sourcing. American Economic Review, 96(5), 1859-1875. http://dx.doi.org/10.1257/aer.96.5.1859

Gupta, A. K., \& Govindarajan, V. (2000). Knowledge flows within multinational corporations. Strategic Management Journal, 2l(4), 473-496. http://dx.doi.org/10.1002/(SICI)10970266(200004)21:4<473::AID-SMJ84>3.0.CO;2-I

Hakanson, L., \& Nobel, R. (2001). Organizational characteristics and reverse technology transfer. Management International Review, 41(4), 395-420. Retrieved from http://www.jstor.org/stable/40658205 
Huang, M.-C., Chiu, Y.-P., \& Lu, T.-C. (2013). Knowledge governance mechanisms and repatriate's knowledge sharing: the mediating roles of motivation and opportunity. Journal of Knowledge Management, 17(5), 677-694. http://dx.doi.org/10.1108/JKM-01-2013-0048

Ietto-Gillies, G. (2005). The product life cycle and international production. In G. Ietto-Gillies, Transnational corporations and international production (pp. 67-80). Cheltenham: Edward Elgar.

Jaw, B.-S., Wang, C. Y. P., \& Chen, Y.-H. (2006). Knowledge flows and performance of multinational subsidiaries: the perspective of human capital. The International Journal of Human Resource Management, 17(2), 225-244. http://dx.doi.org/10.1080/09585190500404481

Jiménez-Jiménez, D., Martínez-Costa, M., \& Sanz-Valle, R. (2014). Knowledge management practices for innovation: a multinational corporation's perspective. Journal of Knowledge Management, 18(5), 905-918. http://dx.doi.org/10.1108/JKM-06-2014-0242

Johanson, J., \& Vahlne, J.-E. (1977). The internalization process of the firm - a model of knowledge development and increasing foreign market commitments. Journal of International Business Studies, 8(1), 23-32. http://dx.doi.org/10.1057/palgrave.jibs.8490676

Johanson, J., \& Vahlne, J.-E. (2009). The Uppsala internationalization process model revisited: from liability of foreigness to liability of outsidership. Journal of International Business Studies, 40(9), 1411-1431. http://dx.doi.org/10.1057/jibs.2009.24

Johnson, W. H. A. (2007). Mechanisms of tacit knowing: pattern recognition and synthesis. Journal of Knowledge Management, 11(4), 123-139. http://dx.doi.org/10.1108/13673270710762765

Kotabe, M., Dunlap-Hinkler, D., Parente, R., \& Mishra, H. A. (2007). Determinants of cross-national knowledge transfer and its effect on firm innovation. Journal of International Business Studies, 38(2), 259-282. http://dx.doi.org/10.1057/palgrave.jibs.8400261

Kumar, N. (2013). Managing reverse knowledge flow in multinational corporations. Journal of Knowledge Management, 17(5), 695-708. http://dx.doi.org/10.1108/JKM-02-2013-0062

Lichtenthaler, U. (2010). Outward knowledge transfer: the impact of project-based organization on performance. Industrial and Corporate Change, 19(6), 1705-1739. https://doi.org/10.1093/icc/dtq041

Li, J. H., Chang, X. R., Lin, L., \& Ma, L. Y. (2014). Meta-analytic comparison on the influencing factors of knowledge transfer in different cultural contexts. Journal of Knowledge Management, 18(2), 278-306. http://dx.doi.org/10.1108/JKM-08-2013-0316

Li, J., Strange, R., Ning, L., \& Sutherland, D. (2016). Outward foreign direct investment and domestic innovation performance: evidence from China. International Business Review, 25(5), 1010-1019. http://dx.doi.org/10.1016/j.ibusrev.2016.01.008

Liu, X., Lu, J., \& Choi, S.-J. (2014). Bridging knowledge gaps: returnees and reverse knowledge spillovers from Chinese local firms to foreign firms. Management International Review, 54(2), 253-276. http://dx.doi.org/10.1007/s11575-013-0185-0

Loane, S., \& Bell, J. (2006). Rapid internationalisation among entrepreneurial firms in Australia, Canada, Ireland and New Zealand: an extention to the network approach. International Marketing Review, 23(5), 467-485. http://dx.doi.org/10.1108/02651330610703409

Luo, Y., \& Tung, R. L. (2007). International expansion of emerging market enterprises: a springboard perspective. Journal of International Business Studies, 38(4), 481-498. http://dx.doi.org/10.1057/palgrave.jibs.8400275 
Maehler, A. E., Curado, C. M. M., Pedroso, E. A., \& Pires, J. P. (2011). Knowledge transfer and Innovation in Brazilian multinational companies. Journal of Technology Management \& Innovation, 6(4), 1-14. http://dx.doi.org/10.4067/S0718-27242011000400001

Makela, K., Bjorkman, I., \& Ehrnrooth, M. (2009). MNC subsidiary staffing architecture: building human and social capital within the organisation. The International Journal of Human Resource Management, 20(6), 1273-1290. http://dx.doi.org/10.1080/09585190902909814

Massini, S., \& Miozzo, M. (2012). Outsourcing and offshoring of business services: challenges to theory, management and geography of innovation. Regional Studies, 46(9), 1219-1242. http://dx.doi.org/10.1080/00343404.2010.509128

Michailova, S., \& Mustaffa, Z. (2012). Subsidiary knowledge flows in multinational corporations: research accomplishments, gaps, and opportunities. Journal of World Business, 47(3), 383-396. http://dx.doi.org/10.1016/j.jwb.2011.05.006

Minbaeva, D. B., Pedersen, T., Björkman, I., \& Fey, C. F. (2014). A retrospective on: MNC knowledge transfer, subsidiary absorptive capacity, and HRM. Journal of International Business Studies, 45(1), 52-62. http://dx.doi.org/10.1057/jibs.2013.56

Moncada-Paterno-Castello, P., Vivarelli, M., \& Voigt, P. (2011). Drivers and impacts in the globalization of corporate R\&D: an introduction based on the European experience. Industrial and Corporate Change, 20(2), 585-603. https://doi.org/10.1093/icc/dtr005

Nair, S., Demirbag, M., \& Mellahi, K. (2015). Reverse knowledge transfer from overseas acquisitions: a survey of Indian MNEs. Management International Review, 55(2), 277-301. http://dx.doi.org/10.1007/s11575-015-0242-y

Najafi-Tavani, Z., Giroud, A., \& Sinkovics, R. R. (2012b). Knowledge-intensive business services: does dual embeddedness matter? The Service Industries Journal, 32(10), 1691-1705. http://dx.doi.org/10.1080/02642069.2012.665895

Najafi-Tavani, Z., Giroud, A., \& Sinkovics, R. R. (2012a). Mediating effects in reverse knowledge transfer processes. Management International Review, 52(3), 461-488. http://dx.doi.org/10.1007/s11575-011-0097-9

Nonaka, I. (1994). A dynamic theory of organizational knowledge. Organization Science, 5(1), 14-37. http://dx.doi.org/10.1287/orsc.5.1.14

Nonaka, I., \& Takeuchi, H. (1995). The knowledge-creating company. New York: Oxford University Press.

Noorderhaven, N., \& Harzing, A.-W. (2009). Knowledge-sharing and social interaction within MNEs. $\begin{array}{lllll}\text { Journal of International Business Studies, 40(5), } & \text { 719-741. }\end{array}$ http://dx.doi.org/10.1057/jibs.2008.106

Öberg, C. (2013). Network imitation to deal with sociocultural dilemmas in acquisitions of young, innovative firms. Thunderbird International Business Review, 55(4), 387-403. http://dx.doi.org/10.1002/tie.21552

Oliveira, M. de M., Jr. (2007). Transferência de conhecimento e o papel das subsidiárias em corporações multinacionais brasileiras. In A. E. Fleury, \& M. T. L. Fleury (Orgs.), Internacionalização e os países emergentes (pp. 216-237). São Paulo: Atlas.

Oliveira, M. de M., Jr., \& Borini, F. M. (2012). The role of subsidiaries from emerging economies-A survey involving the largest Brazilian multinationals. Thunderbird International Business Review, 54(3), 361-371. http://dx.doi.org/10.1002/tie.21467 
Oviatt, B. M., \& McDougall, P. P. (1994). Toward a theory of international new ventures. Journal of International Business Studies, 25(1), 45-64. http://dx.doi.org/10.1057/palgrave.jibs.8490193

Penrose, E. (1959). The theory of the growth of the firm. Oxford: Brasil Blackwell.

Pérez-Nordtvedt, L., Kedia, B. L., Datta, D. K., \& Rashee, A. A. (2008). Effectiveness and efficiency of cross-border knowledge transfer: an empirical examination. Journal of Management Studies, 45(4), 714-744. http://dx.doi.org/10.1111/j.1467-6486.2008.00767.x

Pérez-Nordtvedt, L., Mukherjee, D., \& Kedia, B. L. (2015). Cross-border learning, technological turbulence and firm performance. Management International Review, 55(1), 23-51. http://dx.doi.org/10.1007/s11575-014-0224-5

Petersen, B., \& Ivarsson, I. (2015, November). Political embeddedness and strategic asset seeking of a privately held emerging economy firm: geely's acquisition of Volvo cars corporation. Proceedings of the European International Business Academy Conference, Rio de Janeiro, RJ, Brazil, 15.

Petticrew, M., \& Roberts, H. (2006). Systematic reviews in the social sciences: a practical guide. Malden, MA: Blackwell Publishing Ltd.

Rugman, A. (1975). Motives for foreign intersments: the market imperfections and risk diversification hypothesis. Journal of World Trade Law, 9, 567-573.

Rugman, A. (2006). Internalization as a general theory of foreign direct investment. In A. Rugman, Inside the multinationals: the economics of internal markets (pp. 18-33). Houndmills, Basingstoke; New York: Palgrave Macmillan.

Sanna-Randaccio, F. V., \& Veugelers, R. (2007). Multinational knowledge spillovers with decentralised R\&D: a game-theoretic approach. Journal of International Business Studies, 38(1), 47-63. http://dx.doi.org/10.1057/palgrave.jibs.8400249

Sofka, W. (2008). Globalizing domestic absorptive capacities. Management International Review, 48(6), 769-792. http://dx.doi.org/10.1007/s11575-008-0106-9

Tseng, C. (2015). Determinants of MNC's knowledge inflows to subsidiaries: a perspective on internalization advantages. Management International Review, 55(1), 119-150. http://dx.doi.org/10.1007/s11575-014-0230-7

Vahlne, J.-E., \& Johanson, J. (2014). Replacing traditional economics with behavioral assumptions in constructing the Uppsala model: toward a theory of the evolution of the multinational business enterprise (MBE). In J. J. Boddewyn (Ed.), Multidisciplinary insights from mew AIB fellows (Research in Global Strategic Management, Volume 16, pp. 159-176). New York: Emerald Group Publishing Limited. http://dx.doi.org/10.1108/S1064-485720140000016006

Vance, C. M., Andersen, T., Vaiman, V., \& Gale, J. (2014). A taxonomy of potential contributions of the host country national local liaison role in global knowledge management. Thunderbird International Business Review, 56(2), 173-191. http://dx.doi.org/10.1002/tie.21610

Verbeke, A. (2010). International acquisition success: social community and dominant logic dimensions. Journal of International Business Studies, 41(1), 38-46. http://dx.doi.org/10.1057/jibs.2009.70

Vernon, R. (1966). International investment and international trade in the product cycle. The Quarterly Journal of Economics, 80(2), 190-207. https://doi.org/10.2307/1880689 
Vernon, R. (1993). International investment and international trade in the product cycle. In P. Buckley $\&$ P. Ghauri (Eds.), The Internationalization of the firm: a reader (pp. 14-26). London: Academic Press.

Williams, C., \& Ecker, B. (2011). R\&D subsidiary embedment: a resource dependence perspective. Critical Perspectives on International Business, 7(4), 297-325. http://dx.doi.org/10.1108/17422041111180764

Yin, R. (1994). Applications of case study research. Newburry Park, CA: Sage.

Zaragoza-Sáez, P., \& Claver-Cortés, E. (2011). Relational capital inside multinationals. Knowledge Management Research \& Practice, 9(4), 293-304. http://dx.doi.org/10.1057/kmrp.2011.34

\section{Authors' Profiles}

Clarice Secches Kogut

Rua Pascoal Lemme, 355, Ilha do Fundão, 21941-918, Rio de Janeiro, RJ, Brazil. E-mail address: clarice.kogut@coppead.ufrj.br

Renato Cotta de Mello

Rua Pascoal Lemme, 355, Ilha do Fundão, 21941-918, Rio de Janeiro, RJ, Brazil. E-mail address: renato@ coppead.ufrj.br 


\section{APPENDIX}

\section{Articles from Systematic Review and Their Contribution to Theoretical Framework}

\begin{tabular}{|c|c|c|c|c|c|c|c|c|c|}
\hline & Title & Author & Year & Ant. & $\begin{array}{l}\text { why } \\
\text { (sub) }\end{array}$ & how & what & $\begin{array}{l}\text { why } \\
\text { (par) }\end{array}$ & so what \\
\hline 1 & $\begin{array}{l}\text { Reverse Knowledge Transfer from Overseas Acquisitions: A } \\
\text { Survey of Indian MNEs. }\end{array}$ & Nair et al. & 2015 & & & $\mathrm{x}$ & $\mathrm{x}$ & $\mathrm{x}$ & \\
\hline 2 & $\begin{array}{l}\text { Mediating Effects in Reverse Knowledge Transfer } \\
\text { Processes. }\end{array}$ & Najafi-Tavani et al. & 2012 & $\mathrm{x}$ & & $\mathrm{x}$ & & & \\
\hline 3 & $\begin{array}{l}\text { A Taxonomy of Potential Contributions of the Host Country } \\
\text { National Local Liaison Role in Global Knowledge } \\
\text { Management. }\end{array}$ & Vance et al. & 2014 & & & $\mathrm{x}$ & & & \\
\hline 4 & $\begin{array}{l}\text { An Exploratory Study on International R\&D Strategies of } \\
\text { Chinese Companies in Europe. }\end{array}$ & Di Minin and Zhang & 2010 & & $\mathrm{x}$ & & & & \\
\hline 5 & $\begin{array}{l}\text { Chinese Outward Direct Investment Research: Theoretical } \\
\text { Integration and Recommendations. }\end{array}$ & Deng & 2013 & & & & & $\mathrm{x}$ & \\
\hline 6 & $\begin{array}{l}\text { Cross-Border Learning, Technological Turbulence and Firm } \\
\text { Performance. }\end{array}$ & $\begin{array}{l}\text { Pérez-Nordtvedt } e t \\
\text { al. }\end{array}$ & 2015 & & & & & & $\mathrm{x}$ \\
\hline 7 & $\begin{array}{l}\text { Determinants of MNC's Knowledge Inflows to Subsidiaries: } \\
\text { A Perspective on Internalization Advantages. }\end{array}$ & Tseng & 2015 & & & & & $\mathrm{x}$ & \\
\hline 8 & $\begin{array}{l}\text { Do Overseas R\&D Laboratories in Emerging Markets } \\
\text { Contribute to Home Knowledge Creation? }\end{array}$ & $\begin{array}{l}\text { D'Agostino and } \\
\text { Santangelo }\end{array}$ & 2012 & & $\mathrm{x}$ & & & & \\
\hline 9 & $\begin{array}{l}\text { Drivers and Impacts in the Globalization of Corporate R\&D: } \\
\text { An Introduction Based on the European Experience. }\end{array}$ & $\begin{array}{l}\text { Moncada-Paterno- } \\
\text { Castello et al. }\end{array}$ & 2011 & & $\mathrm{x}$ & & & & \\
\hline 10 & $\begin{array}{l}\text { Effectiveness and Efficiency of Cross-Border Knowledge } \\
\text { Transfer: An Empirical Examination. }\end{array}$ & $\begin{array}{l}\text { Pérez-Nordtvedt } e t \\
\text { al. }\end{array}$ & 2008 & & $\mathrm{x}$ & $\mathrm{x}$ & $\mathrm{x}$ & $\mathrm{x}$ & \\
\hline 11 & $\begin{array}{l}\text { Headquarters' Managerial Intentionality and Reverse } \\
\text { Transfer of Practices. }\end{array}$ & Chung & 2014 & & & $\mathrm{x}$ & & $\mathrm{x}$ & \\
\hline
\end{tabular}




\begin{tabular}{|c|c|c|c|c|c|c|c|c|}
\hline 12 & $\begin{array}{l}\text { Inter-firm Reverse Technology Transfer: The Home Country } \\
\text { Effect of R\&D Internationalization. }\end{array}$ & Criscuolo & 2009 & & $\mathrm{x}$ & & & \\
\hline 13 & $\begin{array}{l}\text { International and Domestic Technology Transfers and } \\
\text { Productivity Growth: Firm Level Evidence. }\end{array}$ & Belderbos et al. & 2013 & & & & & $\mathrm{x}$ \\
\hline 14 & $\begin{array}{l}\text { Knowledge Flows and Performance of Multinational } \\
\text { Subsidiaries: The Perspective of Human Capital. }\end{array}$ & Jaw et al. & 2006 & & & & $\mathrm{x}$ & $\mathrm{x}$ \\
\hline 15 & $\begin{array}{l}\text { Knowledge-intensive Business Services: Does Dual } \\
\text { Embeddedness Matter? }\end{array}$ & Najafi-Tavani et al. & 2012 & & $\mathrm{x}$ & $\mathrm{x}$ & & \\
\hline 16 & $\begin{array}{l}\text { MNC Subsidiary Staffing Architecture: Building Human and } \\
\text { Social Capital Within the Organization. }\end{array}$ & Makela et al. & 2009 & & & $\mathrm{x}$ & & \\
\hline 17 & $\begin{array}{l}\text { Outsourcing and Offshoring of Business Services: } \\
\text { Challenges to Theory, Management and Geography of } \\
\text { Innovation. }\end{array}$ & Massini and Miozzo & 2012 & & $\mathrm{x}$ & & & \\
\hline 18 & $\begin{array}{l}\text { Reverse Transfers of Innovation and National Development: } \\
\text { Evidence from Brazilian Subsidiaries. }\end{array}$ & Bezerra et al. & 2015 & & & $\mathrm{x}$ & & \\
\hline 19 & The Impact of Turbulent Events on Knowledge Acquisition. & Ghauri and Park & 2012 & & & $\mathrm{x}$ & & \\
\hline 20 & $\begin{array}{l}\text { The Role of Subsidiaries from Emerging Economies-A } \\
\text { Survey Involving the Largest Brazilian Multinationals. }\end{array}$ & Oliveira and Borini & 2012 & & $\mathrm{x}$ & & & \\
\hline 21 & $\begin{array}{l}\text { Outward Knowledge Transfer: The Impact of Project-based } \\
\text { Organization on Performance. }\end{array}$ & Lichtenthaler & 2010 & & & $\mathrm{x}$ & & \\
\hline 22 & $\begin{array}{l}\text { Bridging Knowledge Gaps: Returnees and Reverse } \\
\text { Knowledge Spillovers from Chinese Local Firms to Foreign } \\
\text { Firms. }\end{array}$ & Liu et al. & 2014 & & & $\mathrm{x}$ & & \\
\hline 23 & $\begin{array}{l}\text { Knowledge Transfer in Offshore Outsourcing Software } \\
\text { Development Projects: An Analysis of the Challenges and } \\
\text { Solutions from German Clients. }\end{array}$ & $\begin{array}{l}\text { Betz,Oberweis and } \\
\text { Stephan }\end{array}$ & 2014 & & & $\mathrm{x}$ & & \\
\hline 24 & $\begin{array}{l}\text { Network Imitation to Deal with Sociocultural Dilemmas in } \\
\text { Acquisitions of Young, Innovative Firms. }\end{array}$ & Öberg & 2013 & $\mathrm{X}$ & & $\mathrm{x}$ & & \\
\hline 25 & $\begin{array}{l}\text { Trustworthiness, Risk, and the Transfer of Tacit and Explicit } \\
\text { Knowledge Between Alliance Partners. }\end{array}$ & Becerra et al. & 2008 & $\mathrm{x}$ & & & $\mathrm{x}$ & \\
\hline
\end{tabular}


26 Shared Vision in MNE Subsidiaries: The Role of Formal, Personal, and Social Control in Its Development and Its Impact on Subsidiary Learning.

Colakoglu

Valuing Japan-based German Expatriate and Local

Manager's Functions: Do Subsidiary Age and Managerial Bruning et al.

Perspectives Matter?

Hakanson and Nobel

28 Organizational Characteristics and Reverse Technology Transfer.

2001

29 The Art of Knowledge Transfer: Secondary and Reverse Transfer in China's Telecommunications Manufacturing Industry.

Buckley et al.

R\&D Co-practice and 'Reverse' Knowledge Integration in Multinational Firms.

Frost and Zhou

Choi et al.

2003

$\mathrm{X}$

2005

31 Knowledge Governance.

2005

$\mathrm{X}$

32 How Special Is the Special Relationship? Using the Impact of U.S. R\&D Spillovers on U.K. Firms as a Test of Technology Sourcing.

33 Multinational Knowledge Spillovers with Decentralized R\&D: a Game-Theoretic Approach.

Griffith et al.

2006

Sanna-Randaccio and Veugelers

2007

Kotabe et al.

2007
Johnson Synthesis

Using Multi-hub Structures for International R\&D Organizational Inertia and the Challenges of Implementation.

37 Globalizing Domestic Absorptive Capacities.

Criscuolo and Narula

2007

8 Letter from the Editor-in-Chief: Reverse Knowledge Transfers, Culture Clashes and Going International.

39 Knowledge-sharing and Social Interaction within MNEs.
2007

2008

2009

Eden

Noorderhaven and Harzing
2009
$\mathrm{X}$ 


\begin{tabular}{|c|c|c|c|c|c|c|c|c|c|}
\hline 40 & $\begin{array}{l}\text { International Acquisition Success: Social Community and } \\
\text { Dominant Logic Dimensions. }\end{array}$ & Verbeke & 2010 & $\mathrm{x}$ & & $\mathrm{x}$ & & & \\
\hline 41 & $\begin{array}{l}\text { The Multinational Enterprise as a Source of International } \\
\text { Knowledge Flows: Direct Evidence from Italy. }\end{array}$ & Driffield et al. & 2010 & & & & $\mathrm{x}$ & & \\
\hline 42 & $\begin{array}{l}\text { R\&D Subsidiary Embedment: a Resource Dependence } \\
\text { Perspective. }\end{array}$ & Williams and Ecker & 2011 & & $\mathrm{x}$ & & & & \\
\hline 43 & Relational Capital Inside Multinationals. & $\begin{array}{l}\text { Zaragoza-Sáez and } \\
\text { Claver-Cortés }\end{array}$ & 2011 & & & $\mathrm{x}$ & & & \\
\hline 44 & $\begin{array}{l}\text { Knowledge Transfer, Controls, and Performance of MNE } \\
\text { Subsidiaries in the Kingdom of Saudi Arabia. }\end{array}$ & Alharbi and Singh & 2013 & & & $\mathrm{x}$ & & & $\mathrm{x}$ \\
\hline 45 & $\begin{array}{l}\text { Knowledge Governance Mechanisms and Repatriate's } \\
\text { Knowledge Sharing: The Mediating Roles of Motivation and } \\
\text { Opportunity. }\end{array}$ & Huang et al. & 2013 & & & $\mathrm{x}$ & & & \\
\hline 46 & $\begin{array}{l}\text { Managing Reverse Knowledge Flow in Multinational } \\
\text { Corporations. }\end{array}$ & Kumar & 2013 & & & $\mathrm{x}$ & & & \\
\hline 47 & $\begin{array}{l}\text { A Retrospective on: MNC Knowledge Transfer, Subsidiary } \\
\text { Absorptive Capacity, and HRM. }\end{array}$ & Minbaeva et al. & 2014 & & & $\mathrm{x}$ & & & \\
\hline 48 & $\begin{array}{l}\text { Meta-analytic Comparison on the Influencing Factors of } \\
\text { Knowledge Transfer in Different Cultural Contexts. }\end{array}$ & J. H. Li et al. & 2014 & & & $\mathrm{x}$ & & & $\mathrm{x}$ \\
\hline 49 & $\begin{array}{l}\text { Knowledge Management Practices for Innovation: A } \\
\text { Multinational Corporation's Perspective. }\end{array}$ & $\begin{array}{l}\text { Jiménez-Jiménez et } \\
\text { al. }\end{array}$ & 2014 & & $\mathrm{x}$ & & & & \\
\hline 50 & $\begin{array}{l}\text { Accessing vs Sourcing Knowledge: A Comparative Study of } \\
\text { R\&D Internationalization between Emerging and Advanced } \\
\text { Economy Firms. }\end{array}$ & Awate et al. & 2015 & & & & & $\mathrm{x}$ & \\
\hline 51 & The Returns to Foreign R\&D. & Belderbos et al. & 2015 & & & & & $\mathrm{x}$ & \\
\hline \multirow[t]{3}{*}{52} & $\begin{array}{l}\text { Subsidiary Knowledge Flows in Multinational Corporations: } \\
\text { Research Accomplishments, Gaps, and Opportunities. }\end{array}$ & $\begin{array}{l}\text { Michailova and } \\
\text { Mustaffa }\end{array}$ & 2012 & & & & & & $\mathrm{x}$ \\
\hline & & & & 6 & 12 & 26 & 10 & 9 & 6 \\
\hline & & & & $9 \%$ & $17 \%$ & $38 \%$ & $14 \%$ & $13 \%$ & $9 \%$ \\
\hline
\end{tabular}

